\title{
RFLP analysis of the MHC class III region defines unique haplotypes for the non-obese diabetic, cataract Shionogi and the non-obese non-diabetic mouse strains
}

\author{
T. Lund ${ }^{1}$, S.Shaikh ${ }^{1}$, E.Kendall ${ }^{2}$, R. D.Campbell ${ }^{2}$, M.Hattori ${ }^{3}$, S.Makino ${ }^{4}$, A. Cooke $^{5}$ \\ ${ }^{1}$ Department of Immunology and The Medical Molecular Biology Unit, University College London Medical School, London, UK \\ ${ }^{2}$ MRC Immunochemistry Unit, Department of Biochemistry, University of Oxford, Oxford, UK \\ ${ }^{3}$ Joslin Diabetes Center, Harvard Medical School, Boston, Massachusetts, USA \\ ${ }^{4}$ Shionogi Abuhari Laboratories, Shiga, Japan \\ ${ }^{5}$ Division of Immunology, Department of Pathology, University of Cambridge, Cambridge, UK
}

\begin{abstract}
Summary. The non-obese diabetic (NOD) mouse strain which spontaneously develops diabetes is a model for human Type 1 (insulin-dependent) diabetes mellitus. At least one of several genes controlling diabetes in the NOD mouse has been mapped to the MHC. Although previous experiments have implicated the MHC class II genes in the development of the disease, the existence of other MHC linked susceptibility genes has not been ruled out. In order to identify these susceptibility genes we have further characterized the MHC haplotype of the NOD mouse and two non-diabetic sister strains, the non-obese non-diabetic (NON) and cataract Shionogi (CTS). We have examined the mouse MHC class III region for the presence of homologous genes to 17 newly isolated human MHC class III region genes $(\mathrm{G} 1, \mathrm{G} 2, \mathrm{G} 4, \mathrm{G} 6$, G7a/valyl-tRNA synthetase, HSP70, G8, G9, G10, G12, G13,
\end{abstract}

G14, G15, G16, G17 and G18). We detect unique hybridizing DNA fragments for 16 of the 17 genes in six inbred mouse strains (NOD, NON, CTS, B10, BALB/c and CBA/J) indicating that this part of the $\mathrm{H}-2$ region is similar to the human MHC class III region. Using a panel of restriction enzymes we have defined RFLPs for 6 (G2, G6, HSP70, G12, G16, G18) of the 16 cross-hybridizing probes. The RFLPs demonstrate that NOD, NON and CTS mouse strains each have a distinct MHC haplotype in the MHC class III region.

Key words: MHC class III region, non-obese diabetic mouse, non-obese non-diabetic mouse, cataract Shionogi mouse, Type 1 (insulin-dependent) diabetes mellitus, restriction fragment length polymorphisms.
The non-obese diabetic (NOD) mouse which spontaneously develops diabetes, is an animal model for Type 1 (insulin-dependent) diabetes mellitus. As in man the disease in this mouse strain has an autoimmune aetiology. Type 1 diabetes in the NOD mouse is controlled by several recessive genes $[1,2]$ at least one of which, Idd- 1 , has been mapped to the MHC on chromosome 17. Analyses of transgenic NOD mice containing foreign or modified MHC class II genes have demonstrated that the lack of I-E $\alpha$ expression [1] and the unusual sequence of the $\mathrm{A} \beta^{\mathrm{g}^{7}}$-chain [3] are critically important for the diabetic phenotype [4-7]. The NOD mouse strain was developed from a non-inbred cataract prone ICR mouse strain together with two non-diabetic strains, the non-obese non-diabetic (NON) and the cataract Shionogi (CTS) mouse strains [8]. Previous analyses have shown that the NOD and CTS mouse share the same alleles in the MHC class II region, but are different at the H-2D locus [9-11]. The NOD and NON mouse strains share the same functional allele for the H-2D locus [9], but differ in the rest of the classic and non-classic class I and class II loci $[2,9$, 12]. Congenic NOD.CTS-H-2 strains are being estab- lished, and preliminary analysis of these suggests that in addition to the MHC class II genes at least one other MHC-linked gene might influence the diabetogenic phenotype [13].

The MHC contains three major subregions. The highly polymorphic class I and class II regions encode the receptors that bind and present processed antigens to the $T$ cells. More recently additional genes encoding functions involved in the processing and transport of endogenous peptides, and class II-like genes have been identified [1417]. The class III region contains the $S$ region genes that encode components of the complement system. More recently at least 30 novel genes have been identified [16, 1820] some of which encode three heat shock 70 proteins (HSP70) [21] and valyl-tRNA synthetase (G7a) [22]. However, the functions of most of the other novel gene products have yet to be identified.

To further characterize the MHC haplotype of the NOD mouse with the aim of identifying additional susceptibility genes we have used several of the new human MHC class III region cDNAs to compare the haplotype of the NOD mouse with five non-diabetic mouse strains. We 

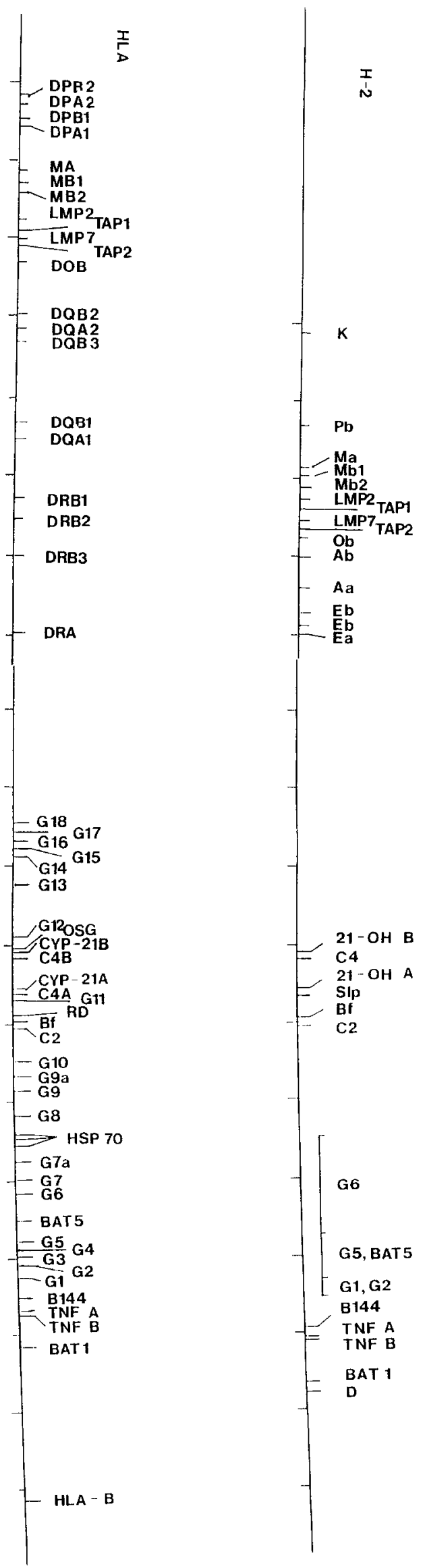

report here that the NOD, NON and CTS mouse strains each have an unique haplotype in the class III region.

\section{Materials and methods}

Mice

The NOD/CRC strain used in this study came from a colony of NOD/Lt mice established at the Clinical Research Centre, Harrow, Middlesex, UK. The NON/Shi/Jos and CTS/Shi/Jos mice were from breeding colonies at the Joslin Diabetes Center, Boston, Mass., USA. The C57BL/10 (B10), BALB/c and CBA/J mice came from colonies at N.I. M.R., London, UK, and the B10.A(2R), B10.A(4R) and $B 10 . A(5 R)$ were also from the Clinical Research Centre.

\section{DNA isolation and Southern blot analysis}

The DNA was extracted from fresh or frozen livers as previously described [12]. The DNA was digested to completion with BamH I, Bgl I, Bgl II, EcoR I, Hinc II, Hind III, Msp I, Pst I, Pvu II, Rsa I, Sac I and Taq I, separated by agarose gel electrophoresis and transferred to Hybond N + (Amersham International, Amersham, Bucks., UK) in $0.4 \mathrm{~mol} / \mathrm{l} \mathrm{NaOH}$. Prior to each hybridization the Southern blots were stripped in $5 \mathrm{mmol} / \mathrm{l}$ Tris- $\mathrm{HCl} \mathrm{pH} 7.5,1 \mathrm{mmol} / \mathrm{I}$ EDTA and $0.1 \times$ Denhardt's $(100 \times$ Denhardt's: $2 \%$ bovine serum albumin, $2 \%$ Ficoll, $2 \%$ polyvinyl-pyrrolidone) at $65^{\circ} \mathrm{C}$ for at least $1 \mathrm{~h}$. The filters were pre-hybridized in $50 \%$ de-ionised formamide, $6 \times \mathrm{SSPE}$ $(1 \times \mathrm{SSPE}: 0.18 \mathrm{~mol} / 1 \mathrm{NaCl}, 10 \mathrm{mmol} / 1$ sodium phosphate $\mathrm{pH} 7.7$, $1 \mathrm{mmol} / \mathrm{I}$ EDTA), $1 \%$ SDS, $5 \times$ Denhardt's, $5 \%$ dextran sulphate and $50 \mu \mathrm{g} / \mathrm{ml}$ of denatured herring sperm DNA for 30 to $60 \mathrm{~min}$ at $65^{\circ} \mathrm{C}$ followed by at least $60 \mathrm{~min}$ at $42^{\circ} \mathrm{C}$. The probes, radioactively labelled according to Feinberg and Vogelstein [23], were added and the filters, hybridized for a minimum of $40 \mathrm{~h}$ at $42^{\circ} \mathrm{C}$, washed in $1 \times$ SSC $(1 \times$ SSC: $150 \mathrm{mmol} / \mathrm{l} \mathrm{NaCl}, 15 \mathrm{mmol} / \mathrm{l}$ sodium citrate $\mathrm{pH} 7.0), 0.1 \%$ SDS at $65^{\circ} \mathrm{C}$ before exposure to Kodak X-OMAT AR-5 X-ray films at $-70^{\circ} \mathrm{C}$ for 3 to 7 days.

\section{DNA probes}

The cDNA clones for the human class III region genes encoding G1, G2, G4, G6, G7a, G8, G9, G9a, G12, G13, G14, G15, G16, G17 and G18 (Fig.1) were obtained by screening a cDNA library from the human monocyte cell line U937 with the appropriate cosmid or genomic probes $[18,20]$. The $\mathrm{G} 10$ probe was a 1.3 kilobase $(\mathrm{kb})$ BamH I/Xho I genomic DNA fragment [18], whilst the HSP70 probe was a $2.4 \mathrm{~kb}$ BamH I/Hind III genomic DNA fragment containing the HSP70-1 gene [21]. The cDNA or genomic DNA inserts were released from the plasmid vectors using suitable restriction endonucleases, purified by agarose gel electrophoresis and spin elution.

\section{Results}

To further characterize the MHC haplotype of the NOD mouse strain compared to other non-diabetic haplotypes, notably that of the CTS mouse strain, we started by deter-

Fig. 1. The MHC class II and class III regions in mouse and man. The relative positions of the complement cluster and the TNF genes in the H-2 complex are as determined by Müller et al. [34]. The approximate mapping of the G2 (BAT 2), G3 (BAT 3), G5 (BAT 4), BAT 5 and G6 (BAT 6) genes was determined using pulse field gel electrophoresis by Lafuse et al. [27]. The organization of the HLA region is as outlined by Trowsdale et al. [35] 


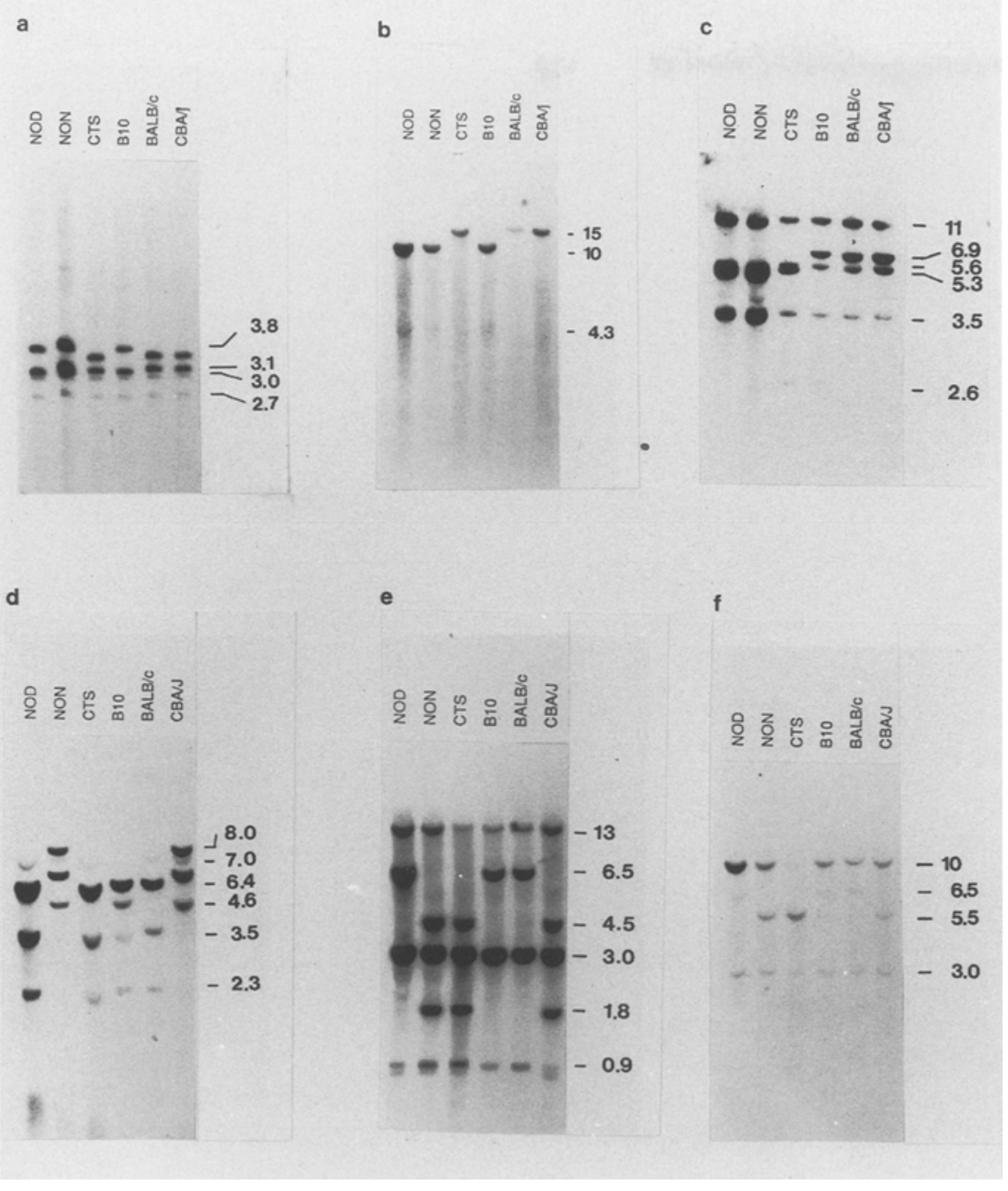

Fig. 2(a-f). Southern blot analysis of mouse MHC class III region genes. Liver DNA $(10 \mu \mathrm{g})$ from the NOD, NON, CTS, $\mathrm{B} 10, \mathrm{BALB} / \mathrm{c}$ and $\mathrm{CBA} / \mathrm{J}$ mouse strains was digested with the appropriate restriction enzyme and hybridized with either cDNA or genomic probes for the human MHC class III region genes

a) the $\mathrm{G} 2 \mathrm{cDNA}$ probe hybridized to $\mathrm{Bgl} \mathrm{I}$ digested DNA

b) the G6 cDNA probe hybridized to Hinc II digested DNA

c) HSP70 genomic probe hybridized to EcoR I digested DNA

d) the G12 cDNA probe hybridized to Taq I digested DNA

e) the G16 cDNA probe hybridized to a Southern blot of EcoRI digested DNA and f) the hybridization profile seen with the G18 probe hybridized to EcoR I digested DNA mining if the mouse MHC contains genes homologous to those recently identified in the human MHC class III region. We used cDNA or genomic probes for 17 of the new class III region genes. The G1, G2, G4, G6, G7a (valyl tRNA synthetase), HSP70, G8, G9, G9a, and G10 genes are located in the region between the $\mathrm{C} 2$ and TNF genes, and the G12, G13, G14, G15, G16, G17 and G18 genes are located between the DR and CYP21B genes (Fig. 1). When hybridized to Southern blots of mouse DNA all but the G8 probe detected one or a few discrete DNA fragments indicating that the mouse genome contains homologous genes for all these human genes (representative blots are shown in Fig. 2). We failed to detect any cross-hybridization with the G8 probe to DNA from mouse, rat or pig suggesting that either this gene is unique to the human genome or that the G8 gene sequences have diverged too much to allow cross-hybridization under the conditions used here.

To establish if any of these human class III region gene probes could be used to characterize the MHC haplotypes of the NOD, NON and CTS mouse strains, we hybridized the probes to Southern blots of genomic DNA, digested with 12 different restriction endonucleases, from these strains. To determine if the putative polymorphic DNA fragments indeed map to the $\mathrm{H}-2$ class III region, we included DNA samples from the C57BL/10 (B10), BALB/C and $C B A / J$ mouse strains and the congenic intra $\mathrm{H}-2$ recombinant mouse strains $\mathrm{B} 10 . \mathrm{A}(2), \mathrm{B} 10 . \mathrm{A}(4 \mathrm{R})$ and $B 10 . A(5 R)$ which allow discrimination of alleles in the class III region (Table 1 ). No RFLPs were detected with the G1, G4, G7a, G9, G9a, G10, G13, G14, G15 and G17 probes. We could, however, detect one or more RFLPs with the probes for the G2, G6, HSP70, G12, G16 and G18 genes (Table 2).

The $\mathrm{G} 2$ probe detects a polymorphic $3.8 \mathrm{~kb} \mathrm{Bgl} \mathrm{I}$ and a polymorphic $11 \mathrm{~kb}$ Bgl II DNA fragment in the NOD,

Table 1. The $\mathrm{H}-2$ haplotypes of the inbred intra-H-2 recombinant mouse strains used

\begin{tabular}{llllllll}
\hline & $\mathrm{K}$ & $\mathrm{A} \beta$ & $\mathrm{A} \alpha$ & $\mathrm{E} \beta$ & $\mathrm{E} \alpha$ & $\mathrm{S}$ & $\mathrm{D}$ \\
\hline $\mathrm{B} 10$ & $\mathrm{~b}$ & $\mathrm{~b}$ & $\mathrm{~b}$ & $\mathrm{~b}$ & $\mathrm{~b}$ & $\mathrm{~b}$ & $\mathrm{~b}$ \\
$\mathrm{BALB} / \mathrm{c}$ & $\mathrm{d}$ & $\mathrm{d}$ & $\mathrm{d}$ & $\mathrm{d}$ & $\mathrm{d}$ & $\mathrm{d}$ & $\mathrm{d}$ \\
$\mathrm{CBA} / \mathrm{J}$ & $\mathrm{k}$ & $\mathrm{k}$ & $\mathrm{k}$ & $\mathrm{k}$ & $\mathrm{k}$ & $\mathrm{k}$ & $\mathrm{k}$ \\
$\mathrm{B} 10 . \mathrm{A}(2 \mathrm{R})$ & $\mathrm{k}$ & $\mathrm{k}$ & $\mathrm{k}$ & $\mathrm{k}$ & $\mathrm{k}$ & $\mathrm{d}$ & $\mathrm{b}$ \\
$\mathrm{B} 10 . \mathrm{A}(4 \mathrm{R})$ & $\mathrm{k}$ & $\mathrm{k}$ & $\mathrm{k}$ & $\mathrm{k}$ & $\mathrm{b}$ & $\mathrm{b}$ & $\mathrm{b}$ \\
$\mathrm{B} 10 . \mathrm{A}(5 \mathrm{R})$ & $\mathrm{b}$ & $\mathrm{b}$ & $\mathrm{b}$ & $\mathrm{b}$ & $\mathrm{k}$ & $\mathrm{d}$ & $\mathrm{d}$ \\
\hline
\end{tabular}


Table 2. Restriction fragments in different mouse strains detected with the different human MHC class III region probes which generated restriction fragment polymorphisms

\begin{tabular}{|c|c|c|c|}
\hline Gene & Enzyme & DNA fragments (kb) & Mouse strains \\
\hline \multirow[t]{2}{*}{$G 2$} & $\mathrm{Bgl} \mathrm{I}$ & $\begin{array}{l}3.8,3.1,3.0 \\
3.5,3.1,3.0\end{array}$ & $\begin{array}{l}\text { NOD, NON, B10, B10.A(4R) } \\
\text { CTS, BALB/c, CBA J, } \\
\text { B10.A(2R), B10.A (5R) }\end{array}$ \\
\hline & Bgl II & $\begin{array}{l}11,3.0,0.6 \\
19,0.6\end{array}$ & $\begin{array}{l}\text { NOD, NON, B10, B10.A(4R) } \\
\text { CTS, BALB/c, CBA J, } \\
\text { B10.A(2R), B10R(5R) }\end{array}$ \\
\hline \multirow[t]{3}{*}{ G6 } & Hinc II & $\begin{array}{l}10 \\
15\end{array}$ & $\begin{array}{l}\text { NOD, NON, B10, B10.A(4R) } \\
\text { CTS, BALB/c, CBA J, } \\
\text { B10.A(2R), B10.A (5R) }\end{array}$ \\
\hline & Taq I & $\begin{array}{l}1.3,1.2,0.9 \\
2.0,1.2,0.7\end{array}$ & $\begin{array}{l}\text { NOD, NON, B10, B10.A(4R) } \\
\text { CTS, BALB/c, CBA } / J, \\
\text { B10.A(2R), B10.A (5R) }\end{array}$ \\
\hline & Rsa I & $\begin{array}{l}4.5,(1.1), 0.5,0.45 \\
3.0,(1.1), 0.5,0.45\end{array}$ & $\begin{array}{l}\text { NOD, NON, B10, B10.A(4R) } \\
\text { CTS, BALB/c, CBA J, } \\
\text { B10.A(2R), B10.A(5R) }\end{array}$ \\
\hline \multirow[t]{2}{*}{ Hsp70 } & EcoRI & $\begin{array}{l}11,5.6,5.3,3.5 \\
11,6.9,5.6,3.5\end{array}$ & $\begin{array}{l}\text { NOD, NON, CTS } \\
\text { B10, BALB/c, CBA/J } \\
\text { B10.A(2R), B10.A }(4 R) \\
\text { B10.A(5R) }\end{array}$ \\
\hline & Sac I & $\begin{array}{l}11,3.8 \\
11,9.2,3.8\end{array}$ & $\begin{array}{l}\text { NOD, CTS } \\
\text { NON, B10, BALB/c, } \\
\text { CBA } / J, B 10 . A(2 R), \\
B 10 . A(4 R), B 10 . A(5 R)\end{array}$ \\
\hline \multirow[t]{3}{*}{$G 12$} & Taq I & $\begin{array}{l}7.0,6.4,3.5,2.3 \\
6.4,4.6,3.5,2.3 \\
8.0,7.0,6.5,4.6\end{array}$ & $\begin{array}{l}\text { NOD, CTS, BALB/c, } \\
\text { B10.A(2R), B10.A }(5 R) \\
\text { B10, B10.A(4R), } \\
\text { NON, CBA } / J\end{array}$ \\
\hline & EcoR I & $\begin{array}{l}20,10,7.8,5.0,3.3 \\
20,10,7.8,5.0,3.0\end{array}$ & $\begin{array}{l}\text { NOD, CTS } \\
\text { NON, B10, BALB/c, } \\
\text { CBA/J, B10.A(2R), } \\
\text { B10.A(4R), B10.A(5R) }\end{array}$ \\
\hline & Hind III & $\begin{array}{l}2.6,1.6,1.2,1.1,0.5 \\
1.6,1.5,1.2,1.1,0.5\end{array}$ & $\begin{array}{l}\text { NOD, CTS, BALB/c, } \\
\text { B10.A }(2 R), B 10 . A(5 R) \\
\text { NON, B10, CBA } / J \\
\text { B10.A }(4 R)\end{array}$ \\
\hline G16 & EcoR I & $\begin{array}{l}13,6.5,3.0,0.85 \\
13,6.5,3.0,0.9 \\
13,4.5,3.0,1.8,0.9,0.85\end{array}$ & $\begin{array}{l}\text { NOD } \\
\text { B10, BALB/c, B10.A(2R), } \\
\text { B10.A(4R), B10.A(5R) } \\
\text { NON, CTS, CBA/J }\end{array}$ \\
\hline G18 & EcoR I & $\begin{array}{l}10,5.5,3.0 \\
5.5,3.0\end{array}$ & $\begin{array}{l}\text { NOD, B10, BALB/c, } \\
\text { B10.A(2R), B10.A(4R), } \\
\text { B10.A(5R) } \\
\text { NON, CBA/J } \\
\text { CTS }\end{array}$ \\
\hline
\end{tabular}

NON, B10 and B10.A(4R) mouse strains but a $3.5 \mathrm{~kb} \mathrm{Bgl}$ I and $19 \mathrm{~kb} \mathrm{Bgl} \mathrm{II} \mathrm{fragment} \mathrm{in} \mathrm{the} \mathrm{CTS,} \mathrm{BALB} / \mathrm{c}, \mathrm{CBA} / \mathrm{J}$, B10.A(2R) and B10.A(5R) mouse strains. An identical strain distribution was seen for the polymorphic fragments detected with the G6 probe. This probe hybridized to a polymorphic $10 \mathrm{~kb}$ Hinc II, a $0.9 \mathrm{~kb}$ Taq I and a $4.5 \mathrm{~kb}$ Rsa I fragment in the NOD, NON, B10 and B10.A(4R) mouse DNA, but a $15 \mathrm{~kb}$ Hinc II, a $0.7 \mathrm{~kb}$ Taq I and a $3.0 \mathrm{~kb}$ Rsa I fragment in Southern blots of CTS, BALB/c, $\mathrm{CBA} / \mathrm{J}, \mathrm{B} 10 . \mathrm{A}(2 \mathrm{R})$ and B10.A(5R) DNA. When hybridized to human DNA the G6 probe also detected, in addition to the fragments derived from the G6 gene, fragments mapping outside the MHC region. The hybridiza- tion pattern of the $\mathrm{G} 2$ and $\mathrm{G} 6$ probes to Southern blots of the intra-H-2 recombinant strains located at least the polymorphic DNA fragments within the MHC class III region (Table 2).

The human MHC class III region contains three loci encoding members of the HSP70 family located between the G7a and G7 genes [21]. When hybridized to mouse DNA, the human HSP70 probe detects, in all digests, two or more predominantly hybridizing DNA fragments, as shown for the EcoR I digested DNA in Figure 2. Prolonged exposure of the autoradiogram showed several additional faintly hybridizing DNA fragments, possibly corresponding to cross-hybridization to other HSP70 


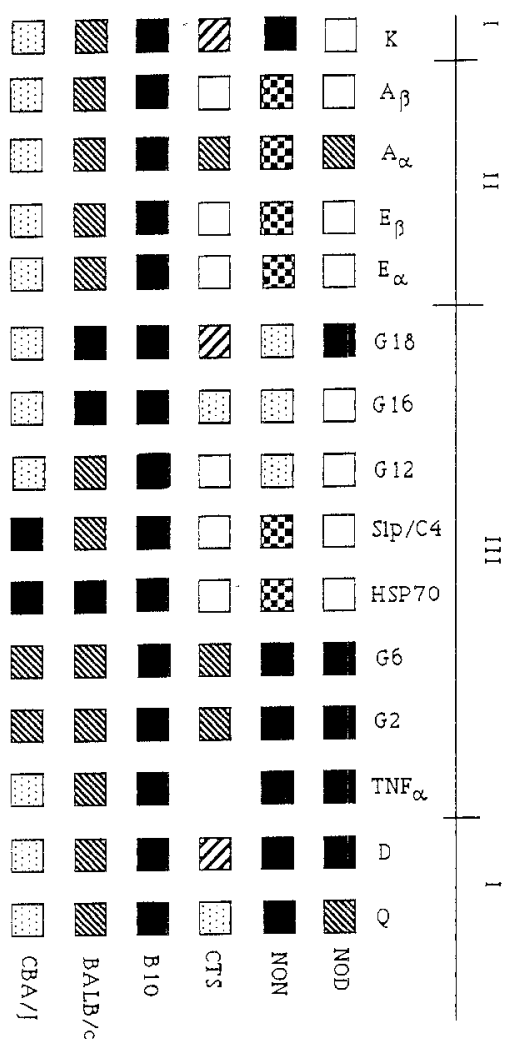

Fig.3. Summary of the MHC haplotype analysis of the NOD, NON and CTS mouse strains. Each symbol represents a unique allele determined on the basis of RFLP analysis $[1,2,9,11,12$, T. Lund unpublished observations], DNA sequencing $[3,10]$ and serological analysis [9]. The B10 haplotype has arbitrarily been chosen to be the predominant haplotype in the diagram. The absence of a haplotype indication for the TNF- $\alpha$ gene in the CTS mouse strain is to indicate that this is unknown at present. It is not clear if the polymorphic DNA fragment detected with the G16 probe is derived from MHClinked gene, because in man the G16 probe detects the G16 gene as well as another gene mapping outside the $\mathrm{MHC}$ region

genes elsewhere in the genome. The HSP70 probe detected RFLPs with two of the 12 enzymes used here. A polymorphic fragment of $5.3 \mathrm{~kb}$ was observed in EcoR I digested DNA of the NOD, NON and CTS mouse strains whilst the HSP70 probe hybridized to a $6.9 \mathrm{~kb}$ polymorphic EcoR I fragment in the DNA of B10, BALB/c and $\mathrm{CBA} / \mathrm{J}$ as well as the intra-H-2 recombinant mouse strains. An additional $9.2 \mathrm{~kb}$ Sac I fragment was seen in the DNA from the NON, B10, BALB/c and CBA/J DNA which appears to be absent from the Sac I digest of DNA from the NOD and CTS mouse strains. The Sac I polymorphism seen in the NOD mouse has previously been mapped to the $\mathrm{H}-2$ region between the Ea and D loci by Gaskin et al. [24]. Very recently Snoek et al. [25] have isolated overlapping cosmid clones containing three mouse HSP70 genes which were linked to the mouse G7a and G7 genes in the MHC class III region.

Hybridization with the G12 probe detects RFLPs with EcoR I, Hind III and Taq I (Fig. 2, Table 2). A polymorphic $3.3 \mathrm{~kb}$ EcoR I fragment was detected in DNA from NOD and CTS only whilst G12 cross-hybridized to a $3.0 \mathrm{~kb}$ polymorphic EcoR I fragment in the DNA from the remaining mouse strains analysed. With Hind III the G12 probe detected, amongst several non-polymorphic bands, also a polymorphic $2.6 \mathrm{~kb}$ fragment in DNA from the NOD, CTS, BALB/c, B10.A(2R) and B10.A(5R) strains, but a $1.5 \mathrm{~kb}$ polymorphic fragment in the DNA from the NON, B10, CBA/J and B10.A(4R) strains. A different hybridization pattern was observed with Southern blots of Taq I digested DNA (Fig.2d). With this enzyme DNA from the NOD, CTS, BALB/c, B10.A(2R) and $B 10 . A(5 R)$ strains can be distinguished from B10 and B10.A(4R) DNA by the presence of a faintly hybridizing polymorphic $7.0 \mathrm{~kb}$ Taq I fragment in the NOD, CTS, $\mathrm{BALB} / \mathrm{c}, \mathrm{B} 10 . \mathrm{A}(2 \mathrm{R})$ and $\mathrm{B} 10 . \mathrm{A}(5 \mathrm{R}) \mathrm{DNA}$, but a $4.6 \mathrm{~kb}$ Taq I fragment in the B10 and B10A(4R) DNA. However, the G12 probe cross-hybridized to a completely different fragment pattern detected in Southern blots of Taq I digested NON and CBA/J DNA. The only two DNA fragments shared with the DNA from the other mouse strains are the two polymorphic fragments of $7.0 \mathrm{~kb}$ and $6.4 \mathrm{~kb}$. Hybridization of the G12 probe to the intra- $\mathrm{H}-2$ recombinant mouse strains maps at least the polymorphic DNA fragments to the MHC class III region (Table 2).

$\mathrm{Bgl}$ II detected an RFLP with the G16 probe showing a polymorphic DNA fragment of $6.5 \mathrm{~kb}$ present in DNA from NOD, B10 and BALB/c, but two polymorphic fragments of $4.5 \mathrm{~kb}$ and $1.8 \mathrm{~kb}$ in the NON, CTS and CBA/J DNA. Furthermore an additional $0.85 \mathrm{~kb}$ DNA fragment seen in EcoR I-digested DNA from the NOD, NON and $\mathrm{CBA} / \mathrm{J}$ strain was not present in DNA from any of the other mouse strains. In man the G16 probe detects in addition to the MHC-linked G16 gene, also one more gene mapping outside the $\mathrm{MHC}$ region. We have not been able to establish how many unlinked DNA fragments the G16 probe detects in the mouse genome, and in particular if the polymorphic DNA fragments described here are in deed derived from sequences linked to the MHC region.

The G18 probe detects a different hybridization pattern in the NOD, NON and CTS mouse strains. A polymorphic $10 \mathrm{~kb}$ and a very faintly hybridizing $6.5 \mathrm{~kb}$ EcoR I fragment were present in the NOD, B10 and BALB/c DNA whilst the G18 probe hybridized to polymorphic EcoR I fragments of $10 \mathrm{~kb}$ and $5.5 \mathrm{~kb}$ in Southern blots of NON and CBA/J mouse DNA. The $10 \mathrm{~kb}$ DNA fragment seems to be completely absent in the DNA from the CTS mouse which only contains the polymorphic $5.5 \mathrm{~kb}$ and the non-polymorphic $3.0 \mathrm{~kb}$ DNA fragments (Fig.2f). Hybridization of the G18 probe to BamH I, Hinc II and Hind III digested DNA detects one predominant hybridizing DNA fragment and one (BamH I) or two (Hinc II and Hind III) very faintly hybridizing DNA fragments suggesting that the human G18 probe only detects one gene in the mouse DNA.

\section{Discussion}

By using cDNA or genomic clones for 17 of the new human class III region genes, contained within approximately $800 \mathrm{~kb}$ of the human class III region, we have demonstrated that 16 of the 17 probes detect discrete DNA fragments in Southern blots of mouse genomic DNA. This confirms and extends the observations for the BAT2 (G2), 
BAT3 (G3), BAT4 (G5), BAT5 and BAT6 (G6) genes recently published by Snoek et al. [26] and Lafuse et al. [27] suggesting that the mouse MHC class III region is homologous to the human MHC class III region. In contrast to the highly polymorphic MHC class I and class II regions, only a limited number of RFLPs have been detected in the mouse class III region by us here or by others recently using other probes $[26,27]$.

The novel RFLPs have nevertheless made it possible for us to further characterize the haplotypes of the NOD mouse and the two non-diabetic sister strains, the CTS and NON strains. Figure 3 summarizes the unique haplotypes of these three mouse strains. Prior analyses have shown that the NOD and the CTS mice differ serologically [9] at the H-2K locus, and that the MHC class II genes including Ea gene are identical [9-11, T. Lund, unpublished observations]. The present analysis defines major differences between the DNA of the NOD and CTS strains in the MHC class III region. If the NOD and CTS MHC haplotypes have been generated by simple recombination between parental haplotypes, the similar RFLP pattern seen for the E $\alpha$ gene and the different allelic forms of the G18 gene would map the cross-over point in the class III region between these two genes.

Functional and serological analyses have shown that the NOD and NON mouse strains share the same allelic form of H-2D [9]. We have previously shown that the NOD and NON mice share the same allelic form of the tumour necrosis factor- $\alpha$ (TNF- $\alpha$ ) gene with the B10 mouse [12]. Our results presented here also show that the $\mathrm{G} 2$ and G6 probes detect the same RFLPs in the NOD, NON, and $\mathrm{B} 10$ mouse strains. The rest of the $\mathrm{MHC}$ region differs greatly between the NOD and NON mouse strains. Our RFLP analysis does not permit us to speculate whether common haplotypes may have been involved in the generation of the NOD and NON MHC haplotypes.

Makino et al. [13] have established congenic NOD.CTS-H-2 mice. Preliminary analysis of the congenic NOD.CTS-H-2 ${ }^{\text {cts/cts }}$ which are homozygous for the CTS MHC haplotype, indicate that these mice have a lower incidence of both insulitis and diabetes compared to the strain NOD.CTS-H-2 $2^{g 7 / g^{7}}$ derived from the same cross [13]. Since the NOD.CTS-H-2 $2^{g 7 / g 7}$ strain are homozygotic for the NOD H-2 haplotype, this suggests the existence of one or more MHC-linked diabetes susceptibility genes outside the MHC class II region. The MHC class III region as shown here differs in these two mouse strains, so this additional susceptibility gene could very well be located in this region. The NOD mouse has been shown to be a low producer of TNF- $\alpha$ in bacterial lipopolysaccharides (LPS) stimulated macrophages and long-term treatment of NOD mice with recombinant TNF- $\alpha$ causes a significant reduction in the incidence of diabetes [28,29]. However, since these effects were also seen for interleukin- $1 \beta$ it is very likely that the 'dysregulation' of the cytokines is dependent on gene products mapping outside the MHC region, and that the TNF- $\alpha$ gene is not identical to the susceptibility gene. Apart from coding for the TNF$\alpha$ and $-\beta$, HSP70s, and valyl-tRNA synthetase (G7a), the functions encoded by the other new class III region genes remain to be established. Loci conferring disease suscepti- bility to a number of diseases have been mapped to this part of the MHC region using conventional genetics. These genes include Hh-1, haemopoetic histocompatibility locus [30]; Cps-1, cleft palate susceptibility locus [31]; Orch-1, orchitis susceptibility locus [25, 32] and Neu-1, a locus influencing neuraminidase activity [33]. To further search for additional diabetes susceptibility genes in the NOD mouse we are presently engaged in isolating intra-H-2 recombinant crosses between NOD and nondiabetic mouse strains. The RFLP analysis does not explain whether any of the sequence polymorphisms or the absence of polymorphic restriction enzyme recognition sequences will affect the expression or function of the respective genes. We have therefore started to isolate the cDNA clones for the mouse MHC class III region genes which will allow us to further characterise the structure and expression of these genes in the NOD and non diabetic mouse strains.

Acknowledgements. We thank Dr. E.Simpson, Clinical Research Centre, Harrow, Middlesex, UK for the NOD and other mouse strains, and Dr. J. Taverne for help in preparing Figure 3. This work was supported by the British Diabetic Association, Arthritis and Rheumatism Council, Wellcome Trust, Middlesex Hospital Medical School Special Trustees, Medical Research Council and Juvenile Diabetes Foundation International.

\section{References}

1. Hattori M, Buse JB, Jackson RA et al. (1986) The NOD mouse: recessive diabetogenic gene in the major histocompatibility complex. Science 231:733-735

2. Prochazka M, Leiter EH, Serreze DV, Coleman DL (1987) Three recessive loci required for insulin-dependent diabetes in nonobese diabetic mice. Science 237: 286-289

3. Acha-Orbea H, McDevitt HO (1987) The first external domain of the nonobese diabetic mouse class II I-A beta chain is unique. Proc Natl Acad Sci USA 84: 2435-2439

4. Uehira M. Uno M, Kurner T et al. (1989) Development of autoimmune insulitis is prevented in $\mathrm{E}$ alpha $\mathrm{d}$ but not in $\mathrm{A}$ beta $\mathrm{k}$ NOD transgenic mice. Int Immunol 1:209-213

5. Lund T, O'Reilly L, Hutchings P et al. (1990) Prevention of insulin-dependent diabetes mellitus in non-obese diabetic mice by transgenes encoding modified I-A beta-chain or normal I-E alpha-chain. Nature 345: 727-729

6. Miyazaki T, Uno M, Uehira M et al. (1990) Direct evidence for the contribution of the unique I-ANOD to the development of insulitis in non-obese diabetic mice. Nature 345: 722-724

7. Slattery RM, Kjer NL, Allison J, Charlton B, Mandel TE, Miller JF (1990) Prevention of diabetes in non-obese diabetic I-Ak transgenic mice. Nature 345: 724-726

8. Makino S, Kunimoto K, Muraoka Y, Mizushima Y, Katagiri K, Tochino Y (1980) Breeding of a non-obese, diabetic strain of mice. Exp Anim 29: 1-13

9. Ikegami H, Makino S, Harada M, Eisenbarth GS, Hattori M (1988) The cataract Shionogi mouse, a sister strain of the nonobese diabetic mouse: similar class II but different class I gene products. Diabetologia 31:254-258

10. Koide Y, Yoshida TO (1990) The unique nucleotide sequence of the A beta gene in the NOD mouse is shared with its nondiabetic sister strains, the ILI and the CTS mouse. Int Immunol 2: 189192

11. Fujishima Y, Koide Y, Kaidoh T, Nishimura M, Yoshida TO (1989) Restriction fragment length polymorphism analysis of major histocompatibility complex genes in the non-obese 
diabetic mouse strain and its non-diabetic sister strains. Diabetologia 32: 118-125

12. Lund T, Simpson E, Cooke A (1990) Restriction fragment length polymorphisms in the major histocompatibility complex of the non-obese diabetic mouse. J Autoimmun 3: 289-298

13. Makino S, Kishimoto Y, Kunimoto K, Kawaguchi J, Uchida K (1991) Localization of the MHC-linked diabetogenic genes of the NOD mouse by using congenic strains. Diabetes Res Clin Pract 14 [Suppl 1]: \$40

14. Trowsdale J, Hanson I, Mockridge I, Beck S, Townsend A, Kelly A (1990) Sequences encoded in the class II region of the MHC related to the 'ABC' superfamily of transporters. Nature 348: 741-744

15. Deverson EV, Gow IR, Coadwell WJ, Monaco JJ, Butcher GW, Howard JC (1990) MHC class II region encoding proteins related to the multidrug resistance family of transmembrane transporters. Nature 348: 738-741

16. Spies T, Bresnahan M, Bahram S et al. (1990) A gene in the human major histocompatibility complex class II region controlling the class I antigen presentation pathway. Nature 348: 744 747

17. Cho SG, Attaya M, Monaco JJ (1991) New class II-like genes in the murine MHC. Nature 353: 573-576

18. Sargent CA, Dunham II, Campbell RD (1989) Identification of multiple HTF-island associated genes in the human major histocompatibility complex class III region. Embo J 8: 2305-2312

19. Spies T, Bresnahan M, Strominger JL (1989) Human major histocompatibility complex contains a minimum of 19 genes between the complement cluster and HLA-B. Proc Natl Acad Sci USA 86: $8955-8958$

20. Kendall E, Sargent CA, Campbell RD (1990) Human major histocompatibility complex contains a new cluster of genes between the HLA-D and complement C4 loci. Nucleic Acids Res 18: $7251-7257$

21. Milner CM, Campbell RD (1990) Structure and expression of the three MHC-linked HSP70 genes. Immunogenetics 32: 242-251

22. Hsieh SL, Campbell RD (1991) Evidence that gene G7a in the human major histocompatibility complex encodes valyl-tRNA synthetase. Biochem J 278: 807-816

23. Feinberg AP, Vogelstein B (1983) A technique for radiolabeling DNA restriction endonuclease fragments to high specific activity. Anal Biochem 132: 6-13

24. Gaskin HR, Prochazka M, Nadeau JH, Henson VW, Leiter EH (1990) Localization of a mouse heat shock Hsp70 gene within the H-2 complex. Immunogenetics 32: 286-289

25. Snoek M, Jansen M, Olavesen MG, Campbell RD, Teuscher C, van Vugt H (1993) Three Hsp70 genes are located in the C4-H-
$2 \mathrm{D}$ region, possible candidates for the Orch-1 locus. Genomics 15: $350-356$

26. Snoek M, Groot PC, Spies T, Campbell RD, Demant P (1991) Fine mapping of the crossover-sites in the $\mathrm{C} 4 \mathrm{H}-2 \mathrm{D}$ region of $\mathrm{H}-2$ recombinant mouse strains. Immunogenetics 34: 409-412

27. Lafuse WP, Lanning D, Spies T, David CS (1992) PFGE mapping and RFLP analysis of the S/D region of the mouse H-2 complex. Immunogenetics 36: 110-116

28. Satoh J, Seino H, Abo T et al. (1989) Recombinant human tumor necrosis factor alpha suppresses autoimmune diabetes in nonobese diabetic mice. J Clin Invest 84: 1345-1348

29. Jacob CO, Aiso S, Michie SA, McDevitt HO, Acha OH (1990) Prevention of diabetes in nonobese diabetic mice by tumor necrosis factor (TNF): similarities between TNF-alpha and interleukin 1. Proc Natl Acad Sci USA 87: 968 972

30. Rembecki RM, Kumar V, David CS, Bennett M (1988) Polymorphism of $\mathrm{Hh}-1$, the mouse hemopoietic histocompatibility locus. Immunogenetics $28: 158-170$

31. Demant $P$ (1985) Corticosteroid-induced cleft palate: cis interaction of MHC genes and hybrid resistance. Immunogenetics 22 : 183-188

32. Teuscher C, Gasser DL, Woodward SR, Hickey WF (1990) Experimental allergic orchitis in mice. VI. Recombinations within the $\mathrm{H}-2 \mathrm{~S} / \mathrm{H}-2 \mathrm{D}$ interval define the map position of the $\mathrm{H}$-2-associated locus controlling disease susceptibility. Immunogenetics 32: 337-344

33. Figueroa F, Klein D, Tewarson S, Klein J (1982) Evidence for placing the Neu- 1 locus within the mouse $\mathrm{H}-2$ complex. J Immunol 129: 2089-2093

34. Müller U, Stephan D, Philippsen P, Steinmetz M (1987) Orientation and molecular map position of the complement genes in the mouse MHC. Embo J 6: 369-373

35. Trowsdale J, Ragoussis J, Campbell RD (1991) Map of the human MHC. Immunol Today 12: $443-446$

Received: 30 December 1992

and in revised form: 2 April 1993

Dr. T. Lund

Department of Immunology

University College London Medical School

40-50 Tottenham Street

London W1P 9PG

UK 